\title{
The dialectics of change in social work education
}

\section{Graeme Simpson ${ }^{1}$, Ani Murr ${ }^{2}$}

\begin{abstract}
The aim of this paper is to explore the dialectics of change in social work education. Beginning with a brief outline of the dialectic, it acknowledges the contested nature of social work, and identifies historical tensions between major stakeholders (government, regulators, employers, academics and educators). It examines inherent contradictions in the understanding of 'good' social work in the conflict over the social work curriculum, and in approaches to the assessment of practice at institutional and individual levels. Significant disconnections between stakeholders identified through the social work degree are described and the potential for reconnection through the reform process in England is recognized. The paper concludes by questioning whether such reconnection (synthesis) is possible in the context of divisive historical tensions (thesis and anti-thesis) and suggesting where new forms of connectivity may emerge
\end{abstract}

Keyword: practice education; social work reform; social work education; dialectics;

1. Senior Lecturer, Social Work. University of Wolverhampton

2. Senior Lecturer, Social Work. University of Wolverhampton.

Address for correspondence: Graeme Simpson, MH122, Faculty of Education, Health and Wellbeing, Nursery Street, Wolverhampton. WV1 1PL. g.simpson@wlv.ac.uk,a.murr@wlv.ac.uk 


\section{Introduction}

This article reviews change in social work education in England, primarily through a textual analysis drawn from historical and current documents (from the mid-1970s to 2014). We therefore concentrate upon key stakeholders: Government, employers and Higher Education Institutes (HEIs) (the providers of social work education): in doing this we acknowledge that they are not the only stakeholders - service users and students being obvious omissions - but rather that Government, employers and HEIs can be identified in the documents throughout the period studied.

The source documents cover a period when the relationship between the four countries that make up the United Kingdom (England, Scotland, Wales and Northern Ireland) has undergone considerable change. From 1999 greater powers have been devolved to Scotland, Northern Ireland and, more latterly Wales and as a result separate systems for England have also developed. The focus of our analysis is exclusively English, as that has been and remains the country of the United Kingdom in which we live and work, and there is not the scope in this paper to deal with the differing trajectories developing in other countries of the UK, as a result of devolution. References to 'the UK' in the text, therefore, relate to the documentation at that time; otherwise we refer to England.

Our perspective is developed from dialectics and we are two 'human actors' (Gramsci, 2003) in the dialectics of two decades of change. During this time we have experienced the fragmentation of the sector revealed through various social work reform processes; been actively involved in the reform of social work education; and, felt the frustration of struggles to reconnect fragmented groups. This, in turn, has created both the background and the impetus for our analysis.

\section{The dialectic: Contradictions and tensions}

The dialectic features throughout much western thought, but is perhaps most often associated with the Hegelian and subsequently Marxist tradition, within which Craib (1997, p.36ff) suggests there are three

94 J. of Practice Teaching \& Learning 13(2-3), pp.93-116. @ wE-b 
dimensions. First there is the totality of the area that is being studied. For us, that would be the development of social work education. A second dimension is the thesis, anti-thesis and synthesis development, which suggests that there are several causes at play before the ideas become 'concrete'. This Hegelian aspect of the dialectic is perhaps the most well known, and the one at the heart of most discussions in this area; for us it is sufficient to note that the development of social work education is multi-causal. In our subsequent analysis the multi-causal factors are identified and expanded upon.

Craib's third dimension is that of contradiction and movement. This is demonstrated throughout our analysis. A cautionary note is offered by Simpson and Connor (2011, p.133), who suggest that an insight of the dialectic is that contradictions and tensions 'are not a secondary aspect or by-product of social reality that can be resolved through policies or calls for harmony and partnership; but constitute the very nature of social reality'. The conflicts and tensions we identify around the social work curriculum throughout our analysis are the reality of social work education, and not an aberrant feature of it.

For Gramsci (2003 p.434ff) the dialectic is played out in the interactions between people and their situation, thus the contradictions created are dependent upon human actions and responses. Callinicos (2004) developed an attendant concept of 'analytical dualism', which maintains the importance of structure and agency. This aspect of the dialectic moves from a theoretical or philosophical analysis to one, which sees human actions at its core. As we have already commented we are 'human actors' in the unfolding analysis and the contradictions and tensions we identify are dependent upon human action or agency. The analysis is not an analysis of 'ideas' alone, but at each turn it is an analysis of how people respond and the interests that are challenged and upheld.

The importance of the dialectic in our argument is the recurrence of tensions, which seemingly create change when going through phases of apparent 'surface resolution'. However, this appearance of change on the surface is contradicted by an unchanged underlying reality, and the tensions resurface in the same, or slightly variant forms (Rojek at al, 1988). These tensions are inherent in both social work, and social work education. Thus, whilst there is an appearance of several changes the underlying tensions remain. Price and Simpson (2007) suggest

95 J. of Practice Teaching \& Learning 13(2-3), pp.93-116. @ w\&b 
that conflict and contradictions are part of the world we live in and that often the outward appearance of change only serves to obscure the realities of continued underlying difficulties, which remain evident in policy arrangements. It is this contradiction within of a seemingly fluid policy in relation to social work education, which is a central theme in our analysis.

\section{Historical tensions: The role and purpose of 'good' social work}

The nature, role and purpose of social work is contested in not only practice but also in social work education, where it is seen in what is taught and assessed (Thompson, 2009; Healy, 2014). Davies (2002, p.1) refers to the variety of the modes of social work, the purpose and nature of which remain 'defiantly elusive', and Price and Simpson (2007) proposed that a series of historical contradictions and tensions lay at the heart of social work and include whether social work is primarily concerned with social reform, social control or social care (Howe, 2009). Simpson and Connor (2011, p.26) argue that 'to understand the full nature of [social work's] ... contemporary role, the historical background needs to be grasped'.

We have accordingly identified three historically significant events. First, a review of social work education in the 1970s; second, the outcry which arose following the implementation of the Diploma in Social Work; and the third, the rise of evidence based practice. These illustrate the nature of the dialectical tensions at the heart of social work, and, taken together demonstrate how a consensus was difficult, if not impossible to reach.

In the 1970s, social work education had little central regulation and offered significant discretion to education providers in the design and delivery of qualifying programmes. During the decade, the Central Council for the Education and Training of Social Work (CCETSW) commissioned consultations, leading to publications of 'Consultative Documents' about the future direction of social work education. Two key proposals were made:

96 J. of Practice Teaching \& Learning 13(2-3), pp.93-116. @ w w b b 
- senior staff at CCETSW should state the aims of qualifying programmes and the type of social workers that programmes should aim to produce,

- that social work programmes should have a shared set of professional values (CCETSW, 1977).

Universities interpreted the proposals as an attempt to introduce central control on social work education, and the nature of social work itself and, therefore, resisted them (Harris 2003; White 2006). The consultations highlighted two key (and subsequently recurring) dialectical themes. First, the role of social sciences in social work was questioned, thereby delineating what counts as legitimate social work theory and method (Bates, 2008). Second, an individualised model of social work was promoted. Students were to recognise their role as 'agents of controlled social change' and to refrain from actions designed to 'change the system', (CCETSW, 1977 p.11, in White, 2006 p.57.) White (2006) and Jones (2011) have argued this was an attempt to steer social work theory and practice away from emerging radical perspectives.

The proposals were not implemented, but this conflict resurfaced in the 1980s, during the preparation for and introduction of the Diploma in Social Work (DipSW), our second historical moment. An extract from a Parliamentary debate on social work education illustrates this:

The public perception of the social worker is confused. He (sic) is looked upon as a do-gooder, a frightening authority figure, a mediator with other services, an ally or an opponent.... Those perceptions arise partly because society as a whole cannot make up its mind whether it wants social workers to help police society for bad families, to relieve it of personal neighbourly responsibilities to the unfortunate, to dispense public charity, or to ensure that public charity is not misused. (Hansard House of Commons, 1986)

Whereas the 1970s conflict was primarily between universities and CCETSW, the views of central government, individual politicians, employers and the media become prominent in the 1980s, when CCETSW presented social work as a state activity moving towards a more radical mandate:

97 J. of Practice Teaching \& Learning 13(2-3), pp.93-116. @ wE-b 
Social work promotes social welfare and responds to wider social needs, promoting equal opportunities for every age, gender, sexual preference, class, disability, race, culture and creed. Social work has the responsibility to protect the vulnerable and exercise authority under statute. (CCETSW, 1989, p.8.)

Central government and the media responded negatively leading CCETSW to revise its radical statements, and return to regulatory discourses for social work (Humphries, 1997). The tensions resurfaced with the publication of CCETSW's second edition of The Rules and Requirements for the Diploma in Social Work, (CCETSW, 1991).

Pinker (1993) noted a 'lethal kind of looniness' in CCETSW's statement about the nature of social work in the proposals for DipSW. Appleyard (1993) echoed this, suggesting the statement rambled on 'with burbling imprecision' and was 'garbage' concluding that the document would see the demise of serious teaching and free debate within social work education. He called on the Secretary of State for Health, Virginia Bottomley, a former social worker, and the Chairman of CCETSW to withdraw the document. She replied:

there will be no place for trendy theories or the theory that '-isms' or '-ologies' come before common sense and practical skills in social work education. (quoted in Bates, 2008 p.63)

Jeffrey Greenwood, the recently appointed Chair of CCETSW, responded:

I don't think the cause of equal opportunities is helped by making statements which I might charitably describe as silly, but others would describe as sinister. I profoundly disagree with the statement. (The Independent, 1993)

He went on to pledge that he would be rooting out the "politically correct nonsense' in CCETSW.

This extract, demonstrates a clear attempt to regulate the curriculum, and thereby, practice by determining what can and cannot be taught, and an attempt to sideline aspects of radical thinking. Harris (2003) comments on this, arguing that it left social workers needing to take account of power, privilege and prejudice whilst leaving their legal and

98 J. of Practice Teaching \& Learning 13(2-3), pp.93-116. @ w w - b 
moral foundations intact. It also shows how a discourse of derision can arise, where concepts are ridiculed, rather than debated (Alexander, 2010).

In this second period of conflict, we can see more clearly the forces of power at work in the dialectical process. This power dynamic was reinforced further, by political changes made within CCETSW, through structural reform and strategic appointments. Humphries (1997, p.646) argued that together these played a significant role in quelling moves towards radical practice and concluded that, 'It became clear that [CCETSW]'s very existence would be at risk if it resisted the changes sweeping other parts of the state'.

This process brought existing tensions in the curriculum into sharp focus. Social work agencies had historically expressed concerns about the academic disciplines being taught, couched in terms of whether their education made them 'difficult employees' more concerned with changing the system than getting on with the job (CCESTW, 1975). The debate, however, was not confined to politicians and employers. Jones (2011) cites an example from the 1970s of social work academics objecting to non-professionally qualified social science academics teaching on social work courses. They argued that these social scientists were contaminating students with ideas that social work perpetuates injustice in society by managing the symptoms of inequality without addressing its causes. Consequently, social work academics and CCETSW worked together to limit the role of non-professionally qualified lecturers. Jones (2011, p.40) concluded that since the 1970s changes in social work education have emphasised the priorities of the agencies, which prefer social workers 'who are doers not thinkers and doers ... who will do as they are told', further reinforcing the inherent power dynamics in the dialectics of social work education.

Our third key historical period saw the rise of the belief that scientific methods could be harnessed to enable public sector provision, including social work, to be delivered more effectively, efficiently and economically as exemplified by Labour Government policy from 1997. The privileging of positivism impacted upon social work by focusing on evidence-based practice in the curriculum, through which its quality and status would be improved (Malin, 2000). This created tensions: Banks (2006) argued it emphasised socially controlling interventions at the expense of understanding the reflexivity of social work; Humphries (2003) argued there was a lack of clarity over what constitutes evidence;

99 J. of Practice Teaching \& Learning 13(2-3), pp.93-116. @ w\&b 
and Bates (2008), highlighted its disregard for the social context, in which social work operates.

The different standpoints on the nature of 'good' social work created conflicting perspectives on what should be included in the taught component of a social work award, who should teach this, and what forms of knowledge should be privileged in the teaching. These tensions or dialectical forces, were increasingly played out in the struggle for a constructively aligned curriculum.

A constructively aligned curriculum (see Biggs, 1999) requires congruence between learning experiences and stated learning outcomes. Moriarty et al (2011) highlight the difficulties multiple perspectives in social work education create, as they each promote different outcomes. They argue that employers are looking for 'fitness for purpose' (the ability to 'do the job'), regulators are looking for 'fitness to practice' and that universities are focusing on 'fitness for award'. The dialectic is again in evidence as this apparent shift, whilst on the surface heralding change, merely restated and repositioned the existing dialectical forces.

\section{The regulation of the assessment of practice}

The social work curriculum comprises learning for and in practice, structured in a variety of ways and settings around university- and work-based modules (Nixon and Murr, 2006). The 'practicum' refers to the part of curriculum, which is located in practice and includes workbased learning experiences and work-place practice assessment. Thus, it is an area where tensions between stakeholders about what is 'good' social work, that is, 'the learning outcomes', are to the fore. Whereas the dialectics of earlier conflicts had clearly involved Government, or quasiGovernmental bodies, this shift underlined the Gramscian analysis of 'human actors', which we identified earlier.

A national framework for the assessment of social work students was first introduced into social work education in the UK with the revised DipSW (CCETSW, 1995), following central government concerns about 'political correctness' (see above). The social work students' ability to practice was measured against six core competences, sub-divided into practice requirements, and specified in performance indicators.

100 J. of Practice Teaching \& Learning 13(2-3), pp.93-116. @ wEb 
A dialectic is inherent in the understanding of competence, which has been as divisive within stakeholder groups as it has been between them. It was heralded as a means of improving the quality of social work practice by demonstrating social workers' attainment and maintenance of occupational standards. Others argued that competence frameworks alone were insufficient and might even be counterproductive. Humphries (1997) predicted its (mis)use, locating the imposition of a competence framework on professional education in the wider context of the development of neo-liberal policy:

The competence approach is reductionist - it assumes that competence is the sum of achieved competences; it lacks the reflective knowledge and understanding which are different from separate skills; it discourages the innovation and creativity necessary to handle unforeseen problems; it reduces ethical and philosophical debate to simplistic and onedimensional 'values'. (Humphries, 1997 p.650)

The competence framework was intended to provide a means to determine whether or not someone was competent, on the basis of evidence. It became reduced to a set of highly atomised competencies, used in assessment of segmented elements of competence, so 'competencies', rather than 'competence', became the problem (McNay et al, 2009). This appears to run counter to the nature of social work outlined in a review of the DipSW:

Social workers do not just need a given set of competences, but they also need the critical thinking, analytical, and inter-personal attributes which are normally associated with 'professionalism'. (J.M. Consulting Ltd, 1999, p.5)

In this review, taken against the recurring backdrop of 'concerns' about social work education, CCETSW argued that employers had unrealistic expectations of newly qualified social workers and, whilst acknowledging concerns about the performance of the social work workforce, countered the blaming of the qualifying award by arguing that all the ills of social work could not be attributed to it. However, a year later, the death Victoria Climbié, brought about increased calls from media and politicians for significant improvement and reform, which took place in the context of the wider political changes instigated

101 J. of Practice Teaching \& Learning 13(2-3), pp.93-116. @ wEb 
by the Labour Government.

Four institutions were established to reform social work and social work education; the General Social Care Council (GSCC), the Commission for Care Standards; the Training Organisation for Personal Social Services (TOPSS) and the Social Care Institute for Excellence (SCIE). CCETSW was abolished and its powers transferred to the GSCC. The qualifying award for social work was changed from the DipSW to a Degree in Social Work (DH, 2002). Perhaps this is further evidence of that aspect of the dialectic, which suggests that surface change masks underlying realities, since the inherent contradictions at the heart of social work education and practice clearly remained.

With the introduction of the social work degree the six core competences were replaced by the National Occupational Standards (NOS) for Social Work (TOPSS. 2002), comprising of 21 units of competence embedded in six key social work roles. The Labour Government oversaw the development and use of competency frameworks across a number of professions, consistent with its view that measurable and evidence-based performance would raise standards, and be economic, efficient and effective. Thus, the tools for the assessment of practice were themselves located in a series of political debates and objectives.

We have outlined a series of policy changes, debates and tensions between a range of stakeholders in social work education, which demonstrate how the concept of dialectics is at the heart of the process. A further layer of tensions is added when we consider how individual practice educators approach assessment.

\section{Practice Education: Individual orientations}

A further dialectical contradiction at the heart of social work education between 'standpoint' and 'objectivity' became increasingly apparent with the use of the NOS as assessment criteria for practice in the social work degree (Cowburn et al. 2000). The underpinning rationale of a competency-based approach to measuring performance in practice is the assessor's neutrality. Cowburn et al (2000) recognised that the scientific positivism (that is, objectivity) on which the competency framework was premised, failed to consider the different social and 
cultural contexts in which competence would be differently understood (standpoint) and applied. The dialectic emerges in its human form as contradictions, debated between stakeholders at a structural level, impact on and are enacted through individual educators whose orientation to the task of assessment is reflexively influenced by themselves and their context.

Practice is assessed for a variety of reasons. The professional purpose is for 'gatekeeping', that is, policing entry into, and protecting standards within, the profession (Evans, 1999; Juliusdottir, et al, 2002; Robertson, 2013). Whilst this comes to the fore when considering failing students (Robertson, 2013) arguably the more educative (pedagogic) purposes of assessment are evident in day-to-day assessment practices.

Personal orientations to the assessment task are identified in education literature. Broadfoot (1998) recognises that the role of assessors' personal values are influential in the positions and styles adopted for assessing. Thus, it is largely accepted that orientations to assessment are not individualistic. Such orientations are developed in communities of practice where what the assessor regards as good (competent) practice is developed with reference to the generally accepted norms in that agency setting (Evans, 1999; Tummons, 2008). Shay (2008) argues that assessment is a social practice, directly influenced by what assessors habitually do in their daily working lives; by the time and place in which they do it; and, by the social, cultural, economic and political contexts in which it is done. Furthermore, assessors, immersed in their practice communities, are often unconscious of the influence these contexts have on how they understand 'good' practice (Schaub and Dalrymple, 2013).

The dialectic between the impact of wider contextual influences and personal orientations is explored in a study of practice assessors' reports (Simpson and Murr, 2013). The study highlights the tension between professional judgement (a socially situated interpretive act) and scientific enquiry (a neutral, objective measurement) in the assessment of practice. Drawing from the work of Tunstall (2001), Tunstall and Gipps (1996) and Morgan et al (2002) a typology of orientations is developed:

- Evaluators, who predominantly consider whether improvement has been made 
- Examiners, who predominantly apply criteria as a template to determine whether a specified standard has been attained

- Advocates, who predominantly look for opportunities to give credit and who seek out ways in which criteria for the standard have been met

- Gate-keepers, who have developed an internalized set of criteria which they apply by considering whether they would want the student as a professional colleague (Simpson and Murr, 2013)

Debates, contradictions and tensions between stakeholders have always been integral to social work education, yet, the introduction of competence as part of the evidence-based positivist project to drive up standards did not work and the fears of those who predicted its reductionist potential were realized (Humphries, 1997). The effect of the dialectical forces here appeared to bring the contradictions to a position where there was, we suggest, no longer a 'debate' being held but rather a disconnection from the process. Although practice educators' orientations to assessment will remain influenced by the social, cultural and political contexts of their work, there was, nevertheless, a need for reconnection amongst stakeholders. An impetus to the final historical event was arguably the case of Peter Connelly, which came to public attention with the trial and conviction of his mother and two other adults for causing the death of a child in 2008. The levels of disconnection and dissatisfaction with the state of social work education across stakeholder groups, as an additional factor, cannot be dismissed lightly.

\section{The reform process: New connections?}

In 2008, the Social Work Task Force was created to review social work and social work education. Early in this review process there was evidence of a clearly fragmented sector. Two reports, (the House of Commons Children, Schools and Family Select Committee (2009) report on 'Training Children and Families Social Workers' and the Social Work Task Force's interim report (2009a)), are summarized by Taylor (2009) as having found that the division of responsibilities between

104 J. of Practice Teaching \& Learning 13(2-3), pp.93-116. (๑) wEb 
universities, employers and regulators was unclear, paving the way for recriminations on all sides. Employers reported that newly qualified social workers were not ready for frontline practice, and declared the social work degree unfit for purpose. Universities stated that employers' expectations of newly qualified social workers were inappropriate, and argued that employers' reluctance to provide placements was a significant factor in social work education's difficulties. In their turn employers expressed views that universities offered inadequate support for practice education, and also that they were reluctant to fail students. Both parties acknowledged weaknesses in the academic and practice components of the social work curriculum: opinion was strongly divided about which needed significant improvement. Employers stated that universities had not got the balance of teaching right with too little attention paid to skills and knowledge for intervening, and too much paid to knowledge for understanding. Universities reported that employers had insufficient numbers of practitioners involved in work-place learning and assessment. The social work regulator (GSCC) was criticised for not ensuring the continuation of sufficiently robust training for practice educators. Local Authorities were criticised for not ring fencing government money given to fund post qualifying social work education, including practice educator training. Practice educators, in the context of university based assessment systems, were criticised for a reductionist interpretation of competence (Taylor, 2009; SWTF, 2009a; HC:CSF, 2009).

The social work review process, highlighting the need for 'a much more collaborative approach' between employers, educators, the government and the profession (SWTF, 2009b, p.9), promoted stronger local partnerships between universities and employers. It concluded that the social work degree was 'not yet reliable enough in meeting its primary objective .... to prepare students for the demands of frontline practice' (SWTF, 2009b, p.16). These recommendations were echoed in a parallel process reviewing child protection social work (Munro, 2011) and the impetus created from these reviews offered the possibility for conflict resolution and reconnection.

Social workers and others have been talking for some time of the problems and potential solutions raised in this report. There is now both

105 J. of Practice Teaching \& Learning 13(2-3), pp.93-116. ๑ w\&b 
an opportunity and an urgent necessity to put things right. Employers, educators and social workers themselves all need to seize this moment. (SWTF, 2009b, p.11)

This was a process of 'reform and review' that appeared to be highly collaborative, and whilst there were inevitable disagreements the dialectical contradictions and tensions had been, to a limited degree, resolved into a new position, which at the very least, offered the prospect of a 're-connected sector'.

Following the final report of the Social Work Task Force, The Social Work Reform Board was charged with implementing the recommendations of the reviews, which they did in the context of other changes within the regulation of social work. There was a change of Government in 2010, and, although there was, in theory at least, all party agreement, not all of the recommendations have been followed, notably in relation to Munro's Report (2011). In 2012 the General Social Care Council was closed and the regulation of social work, was transferred to the Health and Care Professions Council (HCPC).

The College of Social Work (TCSW) was established and has played a significant role in the reform of the social work degree. There was hope that the reform process was achieving reconnection, resolving the tensions between stakeholders in social work education. TCSW produced curriculum guides on key social work theory to help harmonise teaching, and issued templates for the direct observation of practice and for practice educator reports, to bring some standardisation to the assessment of practice in England. TSCW also adopted the Professional Capability Framework (TCSW 2012), devised through the reform process, and has overseen its use in the reformed degree in place of the NOS. The potential for reconnections between stakeholders was further evident in work place learning with the implementation of an improved qualification for practice education and a renewed emphasis in the assessment of capability for 'making what's important assessable rather than making what's assessable important' (TCSW, no date).

106 J. of Practice Teaching \& Learning 13(2-3), pp.93-116. ๑ wEb 


\section{The dialectic resurfaces}

We have highlighted how the dialectic is played out through a range of historical tensions within social work and social work education and, despite the optimism apparent in the paragraph above, these resurfaced during the implementation of the reforms (Moriarty et al, 2011). A Government, which was hostile to Local Authorities, the main employer of social workers, oversaw the reform process and the long standing dialectical contradictions were soon evident in derisive comments about social work theory, what should be taught to social work students, the role of universities, curriculum design and the criteria for the assessment of practice.

Before any students had graduated from the reformed degree, concerns about the quality of social work graduates continued. This emerged in the media as political grievance about the content of teaching. Harry Phibbs, a conservative councillor, exemplified this in a blog post:

Give me a student undertaking a three year social work degree consisting of the most unadulterated Marxist rubbish and I will give you a social worker who puts their warped ideology ahead of the interests of those they are paid to serve. (Phibbs, 2012).

Once more social sciences, critical perspectives or "political correctness' were the target, demonstrating the continuation of this dialectical process. To counter this Robb (2012), argued that the real issues in social work, the dismantling of statutory social services under Coalition policy, were more unpalatable than the social sciences taught in social work degrees.

Under the guise of employer dissatisfaction with social work graduates, and alongside the implementation of significant austerity measures, two further government reviews of social work education were announced in 2013. A comment made in respect of an earlier review of the social work degree could not be more pertinent:

Social work operates in an evolving policy context. However the effects of changes to social work education may take some time to emerge. This may create tensions between being able to demonstrate

107 J. of Practice Teaching \& Learning 13(2-3), pp.93-116. ๑ w\&b 
clear educational outcomes in terms of changes that are attributable to undergoing professional qualifying training and policy pressures to show that wider changes to the delivery of services to children and adults have occurred. (Evaluation of Social Work Degree Qualification England Team, 2008, p.2)

Nonetheless, the two reviews commenced. The Minister for Care and Support commissioned Professor Croisdale-Appleby to review social work education to consider whether it was structured and operated to produce practitioners of high quality. The Secretary of State for Education commissioned Sir Martin Narey to review social work education and training for children and families social workers.

Both reviews drew attention to the number of different documents, from different organisations, which regulated validation, approval and endorsement of social work qualifying awards in England. Narey (2014) argued for one single document from which curriculum design could be developed. Croisdale-Appleby (2014) called for a single regulatory regime for social work education to combine the regulatory assessment frameworks of the HCPC (2012) and TCSW (2012). Taylor and Bogo (2014) argue that the ambiguity about how these two frameworks work together creates tensions or 'fault lines' along which social work qualifying remains divided.

However, despite recognition that less guidance from fewer institutions may help de-fragment and reconnect social work education, the DfE's (2014b) response to Narey's recommendation for a single statement of knowledge and skills has been to report that a knowledge and skills statement has been prepared for child and family social work (DfE, 2014a) and another is under consultation for social work with adults. These statements will be used in practice and education in addition to Standards of Proficiency (HCPC, 2012), Professional Capabilities Framework (TCSW 2012), Social Work Subject Benchmark (QAA, 2008) and TCSW (no date b) curricular guidance. The DfE (2014b) state that such statements 'are not a curriculum guide', but social work qualifying awards are 'encouraged' to review their curricula against it, (DfE, 2014b, p.10).

The tensions around the development of a coherent social work curriculum have also been extended to differences about the preferred mode of delivery for a qualifying award. This gives a renewed impetus 
to a long-standing dialectical tension about delivery, which detracts attention away from the underlying conflict around the nature of social work and the nature of 'good' social work. Additional education providers for workplace, fast-track social work qualifying routes are emerging. 'Frontline: training child protection social workers' received endorsement from the Department of Education in May 2013; and, 'Think Ahead' providing an education for mental health social workers, was launched by the Minister for Care and Support in May 2014. Alongside the already existing 'Step-up to social work programmes', a variety of methods have been developed, some outside the existing regulatory framework, creating new contradictions, tensions and 'disconnects'.

\section{Reconnections?}

Government attention has remained focused on areas which 'need improving', with too little emphasis on what is already 'good' and no time given to allow reforms to effect positive change. Increasingly the impression within the sector is that social work is under constant attack. Michael Gove (2103) in a speech seemingly praising social work, as a 'noble and demanding profession', then reverted to a discourse of dichotomy. First, he attacked a form of social work training which, 'involves idealistic students being told that the individuals with whom they will work have been disempowered by society. They will be encouraged to see these individuals as victims of social injustice whose fate is overwhelmingly decreed by the economic forces and inherent inequalities, which scar our society. This analysis is, sadly, as widespread as it is pernicious'.

Then, he went to argue that 'the best' social workers have rejected this approach, underlining the dichotomy, which, following Alexander's (2010) analysis, limited the options in the debate, and attempting to close it. We have identified how these 'debates' are repeated and there seems to be a remarkable similarity between Gove's comments and those of Bottomley, 20 years earlier (see above). It is perhaps here that the dialectical forces become clearest in that there are two distinct forces in unresolved opposition, and this has been a continuing feature of social work. 
We have outlined how mechanisms for regulation and control have become more, rather than less, complex. There is a near perpetual culture of reviews and revisions, of task forces and working groups, and demands for better training and quality, a recent development being an announcement that there is to be a new accreditation status for child care social workers, beginning with the 'Approved Child and Family Practitioner' status, describes as a 'pass/fail' test (Schraer, 2015). This is, we suggest, yet another 'disconnect' which revisits longstanding debates about standards and quality, with universities and practitioners being on the receiving end of top-down policy initiatives.

We have demonstrated that 'contradictions' arise out of the nature of social work, which is, and perhaps always will be, contested, and can be seen at various levels: Government, professional and regulatory bodies, employers, and the actions of social work educators in universities and practice educators in assessing students' work. Crucially for us, at every level, but significantly in the education and assessment of students, they become dependent upon individual and collective human actions and responses, underlying Gramsci's (2003) account of the dialectic.

We suggest that the historic tensions and conflicts over the nature of social work have been played out as thesis and antithesis, creating some surface resolutions, but change at an underlying level (synthesis) remains elusive. Different forms of social work could be allowed to co-exist rather than perpetuating conflict over restrictive definitions. A range of social work futures could remain in positive dynamic tension. Pessimism about achieving this emanates from the calls for 'needing to improve' through 'reform', 'revision' and 'innovation' without recognizing the 'good'. Optimism comes from developments of alliances across stakeholder groups based on radical perspectives, which are developing strategies for the resistance of neoliberalism and the current austerity measures (Ferguson and Lavalette, 2013; Preston and Aslett, 2014). Alongside these are the longer standing service-user/social workers alliances, which have developed, which can result in movements to improve services and service delivery. Some of the conflicts around the nature of 'good' social work and by extension, 'good social work' are battles for the soul of social work, what this should be and the qualities and skills needed. 'Radical' (Ferguson \& Woodward, 2009), 'engaged' (Simpson \& Connor, 2011),

110 J. of Practice Teaching \& Learning 13(2-3), pp.93-116. @ wE-b 
'humane' (Featherstone et al ,2104) are all restatements of a social work practice which has at its heart the human condition and which take into account the situation people who have difficulties find themselves in and which address questions of power and inequality. In the final analysis the dialectic is about choosing sides: this is ours.

\section{References}

Alexander, R. (2010) Speaking But Not Listening: Accountable talk in an unaccountable context. Literacy, 44, 3, 103-111

Appleyard, B. (1993) 'Why paint so black a picture?' The Independent 4th August. [Accessed 1st January 2015 at http://www.independent.co.uk/ voices/why-paint-so-black-a-picture-a-social-work-directive-elevatesracism-to-a-national-epidemic-it-is-a-national-disgrace-1459106.html]

Authors (2013) The 'Not Yet Competent' Student: Exploring narratives of failure. Journal of Practice Teaching and Learning, 11, 3, 118-134

Banks, S. (2006) Ethics and Values in Social Work. Basingstoke: Palgrave Macmillan

Bates, J. (2008) The Globalisation Discourse, Neo-Liberalism and its Impact on the Education and Training of Social Workers. Ed. D. Thesis, University of Hull

Biggs, J. (1999) Teaching for Quality Learning at University. Buckingham: Society for Research in Higher Education and Open University Press

Broadfoot, P. (1998) Records of Achievement and the Learning Society: A tale of two discourses. Assessment in Education: Principles, policy and practice, $5,3,447-477$

Callinicos, A. (2004 2nd Edition) Making History: Agency, structure, and change in social theory. London: Brill

CCETSW (1975) Second Annual Report. London: Central Council for Education and Training in Social Work

CCETSW (1977) Expectations of the teaching of social work courses leading to the Certificate of Qualification in Social Work (Consultative Document No. 3). London: Central Council for Education and Training in Social Work

CCETSW (1989) Rules and Requirements for the Diploma in Social Work (Paper 30). London: Central Council for Education and Training in Social Work CCETSW (1991) Rules and Requirements for the Diploma in Social Work (Paper

111 J. of Practice Teaching \& Learning 13(2-3), pp.93-116. @ w\&b 
30, 2nd Edition). London: Central Council for Education and Training in Social Work

CCETSW (1995) Assuring Quality in the Diploma in Social Work 1: Rules and Requirements for the Diploma in Social Work. London: Central Council for Education and Training in Social Work

Cowburn, M., Nelson, P. and Williams, J. (2000) Assessment of Social Work

Students: Standpoint and strong objectivity. Social Work Education, 19, 6, 627-637

Craib, I. (1997) Classical Social Theory: and introduction to the thought of Marx, Weber, Durkehim and Simmel. Oxford. Oxford University Press

Croisdale-Appleby, D. (2014) 'Re-visioning Social Work Education: An independent review'. London: David Croisdale-Appleby

Davies, M. (2002) Companion to Social Work. Oxford: Blackwell

Department for Education (2014a) 'Knowledge and Skills for Child and Family Social Work'. [online] [Accessed on 15 January 2015 at https:// www.gov.uk/government/uploads/system/uploads/attachment_data/ file/338718/140730_Knowledge_and_skills_statement_final_version_ AS_RH_Checked.pdf]

Department for Education (2014b) 'Taking Forward Professor CroisdaleAppleby's Review of Social Work Education: Re-visioning social work education - a department of health update'. [online] [Accessed on 7 January 2015 at https://www.gov.uk/government/uploads/system/uploads/ attachment_data/file/383048/review_of_social_work_education_update. pdf]

Department of Health (2002) Requirements for Social Work Training. London: Department of Health

Evans, D. (1999) Practice Learning in the Caring Professions. Aldershot: Ashgate Evaluation of Social Work Degree in England Team (2008) 'Evaluation of the New Social Work Degree Qualification Volume 1: Findings'. London: King's College London and Social Care Workforce Research Unit

Featherstone, B., White, S. and Morris, K. (2014) Re-imagining Child Protection: Towards humane social work with families. Bristol: Policy Press

Ferguson, I. and Lavalette, M. (2013) 'Crisis, Austerity and the Future(s) of Social Work in the UK'. Critical and Radical Social Work, 1, 1, 95-110

Ferguson, I. and Woodward, R. (2009) Radical Social Work in Practice: Making a difference. Bristol: Policy Press

Gove, M. (2013) Speech to the NSPCC: getting it right for children. 12 November. [Accessed on 18 January 2015 at https://www.gov.uk/government/ 
speeches/getting-it-right-for-children-in-need-speech-to-the-nspcc]

Gramsci, A. (2003) Prison Notebooks: Selections. London: Lawrence \& Wishart Hansard HC Vol 92 Cols 1229-34 (28 February 1986)

Harris, J. (2003) The Social Work Business. Oxon: Routledge

Health and Care Professions Council (HCPC) (2012) Standards of Proficiency: Social workers in England'. London: Health and Care Professions Council

Healy, K. (2014) Social Work Theories in Context. Basingstoke: Palgrave Macmillan

Hegel, G.W. F. (1969) Science of Logic. London. Allen and Unwin

House of Commons Children Schools and Families Select Committee. (2009) Training of Children and Families Social Workers: Seventh annual report 2008-09. HC527-1

Howe, D. (2009) A Brief Introduction to Social Work Theory. Basingstoke: Palgrave Macmillan

Humphries, B. (1997) Reading Social Work: Competing discourses in the rules and requirements for the diploma in social work. British Journal of Social Work 27, 641-658

Humphries, B. (2003) What else counts as evidence in evidence-based social work? Social Work Education 22, 1, 81-91

J. M. Consulting Ltd (1999) Review of the Diploma in Social Work: Report on the contents of the DipSW conducted as part of the stage two review of CCETSW. Bristol: JMC Ltd

Jones, C. (2011) The Best and Worst of Times: Reflection on the impact of radicalism on British social work in the 1970s. in Lavelette, M. (Ed) Radical Social Work Today: Social work at the crossroads. Bristol: Policy Press Juliusdottir, S., Hrafnsdottir, S. and Kristjansdottir, B. (2002) Student Practice Placements as Gatekeepers to the Profession. in Shardlow, S. and Doel, M. (Ed) Learning to Practise. London: Jessica Kingsley Press

Malin, N. (2000) Professionalism and Boundaries of the Formal Sector: The example of social and community care. in Malin, N. (Ed) Professionalism, Boundaries and the Workplace. London: Routledge

McNay, M., Clarke, J. and Lovelock, R. (2009) The Journey Towards Professionalism in Social Work: The development of assessment and practice learning. Journal of Practice Teaching and Learning, 9, 3, 72-91

Morgan, C., Tsatsaroni, A. and Lerman, S. (2002) Mathematics Teachers' Positions and Practices in Discourses of Assessment. British Journal of Sociology of Education, 23, 3, 445-461

Moriarty, J., Manthorpe, J., Stevens, M. and Hussein, S. (2011) Making the

113 J. of Practice Teaching \& Learning 13(2-3), pp.93-116. @ wEb 
Transition: Comparing research on newly qualified social workers with other professions. British Journal of Social Work, 41, 1340-1356. Cited in Taylor, I. and Bogo, M. (2014) Perfect Opportunity Perfect Storm? Raising the standards of social work education in England. British Journal of Social Work, 44, 1402-1418

Munro, E. (2011) 'The Munro Review of Child Protection: Final report - a child centred process, Cm8062. London: Department of Education

Narey, M. (2014) 'Making the Education of Social Workers Consistently Effective'. London: Department for Education

Nixon, S. and Murr, A. (2006) Professional Learning and the Development of Professional Practice. Social Work Education, 25, 8, 798-811

Pinker, R. (1993) 'A lethal kind of looniness'. Times Higher Education Supplement. 10th September, p19

Phibbs, H. (2012) 'Social Work Training is where the Seeds of Scandal are Sown'. [Blog entry 26 November] [Accessed in 7 January 2015 at http://www. conservativehome.com/localgovernment/2012/11/social-work-trainingis-where-the-seeds-of-scandal-are-sowed.html]

Preston, S. and Aslett, J. (2014) 'Resisting Neoliberalism from within the Academy: Subversion through an activist pedagogy'. Social Work Education, $33,4,502-518$

Price, V. and Simpson, G. (2007) Transforming Society? Social work and sociology. Bristol: Policy Press

Quality Assurance Agency (QAA) (2008) Subject Benchmark Statement: social work. Gloucester: Quality Assurance Agency

Robb, B. (2012) 'Prejudiced Attacks on Social Work Training Ignores Real Issues Facing Profession'. Community Care, 30 November. [Accessed on 7 January at http://www.communitycare.co.uk/2012/11/30/prejudicedattack-on-social-work-training-ignores-real-issues-facing-profession/]

Robertson, J. S. (2013) Addressing Professional Suitability in Social Work: Results of a study of field education coordinators' experience. Journal of Practice Teaching and Learning, 11, 3, 98-117

Rojek, C., Peacock, G. and Collins, S. (1988) Social Work and Received Ideas. London: Routledge

Schaub, J. and Dalrymple, R. (2013) Surveillance and Silence: Considerations in assessing difficult social work placements. Journal of Practice Teaching and Learning, 11, 3, 79-97

Schraer, R. (2015) 'Children's social workers set controversial pass or fail test to practice.' Community Care 28 January [Accessed on 30 January 2015 at 
http://www.communitycare.co.uk/2015/01/28/childrens-social-workersset-pass-fail-test-practise/]

Shay, S. (2008) Researching Assessment as Social Practice: Implications for research methodology. International Journal of Educational Research, 47, 159-164

Simpson, G. and Connor, S. (2011) Social Policy for Social Welfare Professionals. Bristol: Policy Press

Simpson, G. and Murr, A. (2013) The 'not yet competent' student: exploring narratives of failure. Journal of Practice Teaching and Learning, 11, 3, $118-134$

Social Work Task Force (2009a) 'Facing up to the Task: The interim report of the social work task force. London: Department for Children, Schools and Families

Social Work Task Force (2009b) 'Building a Safe, Confident Future: The final report of the social work task force. London: Department for Children, Schools and Families

Taylor, I. and Bogo, M. (2014) Perfect Opportunity Perfect Storm? Raising the standards of social work education in England. British Journal of Social Work, 44, 1402-1418

Taylor, A. (2009) 'MPs and Social Work Task Force Propose Overhaul of Social Work Training'. Community Care, August 19. [Accessed on 15th January 2015 at http://www.communitycare.co.uk/2009/08/19/mps-andsocial-work-task-force-propose-overhaul-of-social-work-training/]

The College of Social Work (2012) The Professional Capabilities Framework. London: TCSW

The College of Social Work (no date a) Creating a New Way of Thinking about Skills, Knowledge and Values Social Workers Use in their Practice: capabilities rather than competencies. TSCW website [Accessed on 15 January 2015 at http://www.tcsw.org.uk/Curriculum-Guides/]

The Independent. (1993) 'Social workers to shed 'politically correct' image'. The Independent [online] 23rd August. [Accessed 1st January 2015 at http:// www.independent.co.uk/news/social-workers-to-shed-politically-correctimage-in-an-exclusive-interview-the-new-chief-of-social-work-trainingtells-rosie-waterhouse-his-plans-1462898.html]

Thompson, N. (2009) Understanding Social Work. Basingstoke: Palgrave Macmillan

Training Organisation for Personal Social Services (2002) National Occupational Standards for Social Work. Leeds: Training Organisation for Personal Social Services England UK Partnership

115 J. of Practice Teaching \& Learning 13(2-3), pp.93-116. @ w\&b 
Tummons, J. (2008) Assessment, and the Literacy Practices of Trainee PCET Teachers. International Journal of Educational Research, 47, 184-191

Tunstall, P. (2001) Assessment Discourses and Constructions of Social Reality in Infant Classrooms. Journal of Education Policy, 16, 3, 215-231

Tunstall, P. and Gipps, C. (1996) Teacher Feedback to Young Children of Formative Assessment: A typology. British Educational Research Journal, $22,4389-404$

White, V. (2006) The State of Feminist Social Work. Abingdon: Routledge 